\title{
Diversity-Productivity Relationship in the Northeastern Tamaulipan Thornscrub Forest of Mexico
}

\author{
Jose Navar, ${ }^{1}$ F. de Jesus Rodriguez-Flores, ${ }^{2}$ \\ Pedro A. Dominguez-Calleros, ${ }^{3}$ and Gustavo Perez-Verdin ${ }^{4}$ \\ ${ }^{1}$ Natural Resource Management, Instituto Politécnico Nacional Unidad Durango, \\ Sigma No. 119. Fraccionamiento 20 de Noviembre II, 34220 Durango, DGO, Mexico \\ ${ }^{2}$ Tecnología Ambiental, Universidad Politécnica de Durango, Km 9.5 Carr., 34600 Durango, DGO, Mexico \\ ${ }^{3}$ Forestry, Facultad de Ciencias Forestales, Universidad Juárez del Estado de Durango, \\ Avenida Río Papaloapán s/n. Col. Valle del Sur., 34660 Durango, DGO, Mexico \\ ${ }^{4}$ Forest Economics, Instituto Politécnico Nacional Unidad Durango, \\ Sigma No. 119. Fraccionamiento 20 de Noviembre II, 34220 Durango, DGO, Mexico
}

Correspondence should be addressed to Jose Navar; jnavar@ipn.mx

Received 22 March 2013; Revised 29 September 2013; Accepted 7 November 2013; Published 5 January 2014

Academic Editor: Ram C. Sihag

Copyright (C) 2014 Jose Navar et al. This is an open access article distributed under the Creative Commons Attribution License, which permits unrestricted use, distribution, and reproduction in any medium, provided the original work is properly cited.

\begin{abstract}
This research examines the diversity-productivity relationship in a semiarid scrubland, initially under late successional conditions and subsequently under early successional conditions created by experimental clearing, to explore the roles that productivity and stochastic mortality play in species exclusion in this environment. A total of fifteen plots were studied by measuring environmental conditions and biomass components of shrubs and seedlings. These stands were distributed along a productivity gradient across five different landforms. A hypothesis about the stochastic self-thinning mortality model along the gradient was evaluated with the diversity-productivity-environment data. The diversity-productivity relationship was linear and reversed between the early and late succession stages. The hypothesis of stochastic mortality of species exclusion was rejected in the early stages of succession and partially accepted in the mature stage of succession. Species exclusion was negatively related to productivity gradients, suggesting that strong interspecific competition occurs in high productivity plots and that a larger number of species can survive in higher abiotic stress landscapes. Further research is needed to understand the temporal and spatial variations of the ecological interactions that shape this plant community.
\end{abstract}

\section{Introduction}

Environmental gradients offer ideal conditions for exploring the interactions between evolutionary adaptations and ecological processes over short spatial distances. Productivity [1], temperature [2], evapotranspiration [3], and the energy and water balance [2] are potential drivers of species diversity that can vary significantly over short distances, within the dispersal range of a species pool. However, local regional peculiarities such as fires, land use, or drought may obscure interpretation of the response of species diversity to environmental gradients.

Productivity is probably the single most important and most studied driver of species diversity because it is a function of several other critical factors such as the energy and water balance, evapotranspiration, and temperature [13]. Productivity is defined as the amount of plant mass produced over a certain time in a given area. Productivity is influenced by genetic adaptations and site environmental factors. Plant productivity is technically defined as net primary productivity or NPP, which is the difference between photosynthesis (gross primary productivity) and the total respiration of plants in an ecosystem. Both components are difficult to measure in the field at the spatial scales of interest [4]. Therefore, the net plant growth has been considered an estimator of NPP at short temporal scales where recruitment and mortality are absent.

Net primary productivity typically changes over time as plants increase in size, and species composition changes over 
the course of succession [5]. A linear relationship between productivity and species diversity has been reported for grasslands in several regions. However, many studies across a wide range of productivity conditions find a unimodal or hump-backed pattern in which diversity increases with productivity, reaches a maximum at intermediate levels of productivity, and decreases in highly productive sites $[1,5-7]$. Abrams [8] pointed out that there are good theoretical reasons to predict a variety of differential relationships between diversity and productivity. Mittelbach et al. [1] summarized 171 observations on diversity-productivity relationships and found the unimodal pattern was the most common, followed by the monotonic and the $U$-form models. Grime [7], Huston [5], Rosenzweig [9] and Waide et al. [10] indicated that the hump-back pattern is frequently observed in multiple taxas and at several scales of measurement.

The relationship between diversity and productivity has been studied primarily in grasslands or ruderal vegetal communities $[6,11,12]$ because these short-lived species provide a quick response to environmental changes. Mittelbach et al. [1] recorded only five studies using shrubs and trees exclusively. Mittelbach et al. [1] suggested the need for observing the diversity-productivity relationship under field conditions in different ecosystems in order to understand and model the relationship more accurately. This would help to provide conceptual bases for the sustainable management and conservation of forest ecosystems.

The mechanisms that create the diversity-productivity patterns are not fully resolved. It seems that diversity increases as productivity increases, and this trend grows monotonically or decays in more productive sites, in agreement with the unimodal model. Along many productivity gradients, there is a clear tendency for diversity to diminish under highly productive conditions. That is, sites with intermediate productivity have greater species diversity than more productive sites $[6,7,11,13]$.

Two hypotheses have been put forth to explain the species diversity reduction where productivity is high: competitive exclusion by inter-specific competition (CEI), and the $-3 / 2$ law of the self-thinning mechanism at the level of the species assembly (ST) [11, 14]. In the first mechanism, inter-specific competition for limited resources promotes species exclusion $[6,7,13]$. In the second mechanism, the species disappearance is explained by random processes associated with the stand density reduction as individual size increases with time. In this stochastic mortality process, rare species have a probability of disappearance equal to individuals of more abundant species, and so are more likely to disappear because of their small population size. These effects of productivity on species diversity can reverse completely depending on the relative levels of disturbance and growth rates [13].

In spite of the extensive management of the Tamaulipan thornscrub plant community for ranching and forestry practices since early 1700's [15]; contemporary land use changes [16] are: (a) modifying the local hydrology of this ecosystem $[17,18]$, (b) increasing the risk of extinction of several endemic and already endangered flora and fauna species $[19,20]$, and (c) contributing to potential global climate change by releasing carbon stocks contained in soils and biomass [16]. Due to high contemporary deforestation rates by gas mining in the region, restoration efforts of the plant community are underway [20] but information is required on the spatial and temporal changes of tree diversity and what may be the potential drivers of these shifts. Therefore, this research had the following objectives: (i) to determine the relationship between diversity and productivity in the early and mature stages of succession of plant communities in the Tamaulipan thornscrub plant community, (ii) to identify the possible mechanisms that control these relationships, including testing the hypothesis of stochastic mortality, and (iii) to understand the spatiotemporal patterns of these relationships and the mechanisms that may cause them to change over time.

\section{Materials and Methods}

2.1. Study Area. This research was conducted in the Tamaulipan thornscrub forest reserve of the Faculty of Forest Sciences, UANL, located in the city of Linares, N. L. in the Coastal Plain of the northern Gulf of Mexico. This physiographic region spans an area of $200,000 \mathrm{~km}^{2}$ in northeast Mexico and the southern United States. In northeastern Mexico, this ecosystem is in a state of transition due to rapid land use changes [16,21]. The study area is located at 360 masl and is characterized by a warm, semi-arid, subtropical climate with an annual average precipitation of $745 \mathrm{~mm}$ (standard deviation, $250 \mathrm{~mm}$ ) over an average of 80 rain events, of which $5 \%$ exceed $20 \mathrm{~mm}$ of rainfall. The annual average temperature is $22^{\circ} \mathrm{C}[22,23]$.

The soils are derived from the Sierra Madre Oriental mountain range, which is composed of limestones and other sedimentary rocks uplifted by the orogeny that began near the end of the Upper Cretaceous and continued into the Paleocene period. These movements occurred simultaneously with the extension of the coastal plain of the present Gulf of Mexico. In general, the soil formation is influenced by its topographic position. The soil texture varies from loamysandy to clayey soils, with a wide range of colors, from gray to greenish and yellowish brown [24].

The Tamaulipan thornscrub plant community is diverse and is found on a wide variety of landforms. The floodplains in the lowest parts of the landscape are characterized by their proximity to intermittent or ephemeral streams, deep soils, and high availability of soil moisture during and shortly after the rainy season. Here, plants are characterized by larger size than anywhere else in the Tamaulipan thornscrub community. Following the gradient upslope, most of the landscape consists of valleys or open plains with deep to moderately deep clay soils, good fertility, and vegetation of medium height. Hills are conspicuous in the landscape and have high slopes and are usually crowned by mesas or plateaus that have shallow soils and low fertility levels. Finally, the elevated mesas or plateaus appear as isolated components of the landscape; they display shallow, thin, and stony soils, with scarce, short plant cover.

In general, the plant cover is characterized by species such as Ebenopsis ebano, Zanthoxylum fagara, Acacia farnesiana, 
Cordia boissieri, Caesalpinia mexicana, and Celtis pallida. These taxa have high abundance and cover [25]. The vegetative cover is dominated by shrubs $(72.8 \%)$ and herbaceous plants (27.2\%) [19]. Historically, the vegetation of the study area has been managed with conventional pasturing, as the land was extensively used for cattle ranching. However, the study area has been protected from this practice for approximately 30 years.

2.2. Sampling. Sampling consisted of establishing fifteen plots of $5 \mathrm{~m} \times 5 \mathrm{~m}$, with three located on each of five landforms: (1) intermittent floodplain, (2) ephemeral floodplain, (3) valleys, (4) high-sloped terrain, and (5) mesas or plateaus. Replicates on each landform were separated by a distance of at least 20 meters. Therefore, the experimental design was stratified by landform with replicate plots positioned randomly within each landform. The five landforms created a productivity gradient within a linear distance of $1.5 \mathrm{~km}$ and an altitudinal range of $45 \mathrm{~m}$.

In each plot, data collection for estimating diversity consisted of measuring basal diameter, top height, and cover for each shrub present in the stand (by measuring the vertical projection of the canopy). Total aboveground biomass was estimated by harvesting all existing vegetation, freshly weighed for each individual shrub; samples of biomass components (foliage, branches, and boles) were taken, freshly weighed and oven-dried, and the ratio of dry/fresh samples was used for estimation of the dry matter by biomass component by shrub, by species and finally by plot. Aboveground productivity was estimated by giving the harvested plots a year to grow seedlings, either by seed or by sprouting, and then repeating the same procedure for estimating the diversity and seedling biomass. With this experimental design, information was first collected on tree diversity and aboveground biomass for the later stages of succession and, later following a year of regrowth after complete harvesting, on the biomass, diversity and productivity for the early stages of succession. Total aboveground biomass was correlated with productivity; henceforth, an estimate of productivity for the later stages of succession was derived. In this manner, potential changes in the relationship between diversity and productivity over time were determined.

Other measured productivity correlates included soil nitrogen content, soil organic matter, and soil organic carbon in the upper $30 \mathrm{~cm}$ of soil. Organic matter content was measured by wet combustion according to a modified Walkley/Black methodology [24]. Soil nitrogen content was estimated by means of the digestion of total nitrogen according to the procedure of Kjeldahl. The soil texture was also measured by the Bouyoucos methodology.

2.3. Statistical Analysis. A correlation analysis was conducted between diversity ( $S=$ species richness), density (Den = density), and environmental (Text = texture, $\mathrm{N}=$ nitrogen content, $\mathrm{CC}=$ carbon content, and $\mathrm{CN}=$ carbon/nitrogen ratio) variables for both early and late successional stages. The diversity-productivity relationship was evaluated by fitting quadratic, linear, and second-degree polynomial regressions, where the aboveground productivity, $P$, is the independent variable that predicts species diversity, $S$, for example, $[S=$ $\left.a+b(P)+c(P)^{2}\right]$. The probabilities of the statistical parameters $a, b$, and $c$ define which is the best model. For example, the statistical significance of $a, b$, and $c$ can indicate a humpback or $U$-form relationship depending on the signs of the coefficients $b$ and $c$. A lack of significance for $c$ indicates that the diversity-productivity relationship fits the monotonic model.

If the unimodal or $U$ form model defines the relationship between productivity and diversity, the species loss in high productive gradients suggests two possibilities: (a) mortality by inter-specific competition or (b) random, stochastic mortality. In order to test the first hypothesis, studies on the physiology and ecology of the present species are required, but this is not the focus of this research. The second hypothesis can be tested by fitting empirical models. To do so, it is necessary to establish the relationships between density, productivity, and diversity based on density. The first relationship is described by the following function (1):

$$
D(P)=\alpha_{0}+\beta_{0}(P),
$$

where $D(P)$ is total density (number of stems per ha), $P$ is the parameter of productivity, measured as total aboveground NPP ( $\mathrm{Mg} \mathrm{ha}^{-1}$ year $\left.^{-1}\right)$, and $\alpha_{0}$ and $\beta_{0}$ are empirical constants.

The relationship between diversity and density is described by (2)

$$
S(D)=\alpha_{1}+\beta_{1}(D)
$$

where $S(D)$ is diversity with stand density $(D), D$ is stand density (number of shrubs per ha), and $\alpha_{1}$ and $\beta_{1}$ are empirical constants.

Equations (1) and (2) are combined in (3), which defines the increase or decrease in species diversity as a function of productivity as follows:

$$
S=\alpha_{1}+\beta_{1}\left[\alpha_{0}+\beta_{0}(P)\right],
$$

where $\alpha_{0}, \alpha_{1}, \beta_{0}$, and $\beta_{1}$ are empirical constants.

The size (basal diameter, top height) distributions of the species, the number of individuals, and the productivity of individual species or individuals of different sizes plotted in the altitudinal gradient allow us to draw some inferences about the role of competition, as well.

\section{Results}

The species richness of seedlings and sprouts after a year of growth following complete harvest was 37 species, distributed in 10 families and 31 orders (Table 1). The growth forms of these species are characterized as $70 \%$ shrubs, $18.9 \%$ small shrub, 5.4\% herbaceous, and $2.7 \%$ trees and lianas (Table 1 ). In this early stage of succession, the legume family was the most abundant and most dominant. The mean number of species per $25 \mathrm{~m}^{2}$ across landforms was 8 , with a standard deviation of 2 species. There was an observed tendency for increased species diversity from the plateaus to the 
TABLE 1: Floristic listing of the present species in the sampling sites and the landforms on which they occurred.

\begin{tabular}{|c|c|c|c|c|}
\hline Scientific name & Code & Family & Form & Landform \\
\hline Viguiera stenoloba Blake & Vig ste & Asteraceae & Shrub & De, Val \\
\hline Brickellia spp. & Bric & Asteraceae & Herbaceous & $\mathrm{De}$ \\
\hline Gochnatia hypoleuca DC. & Goc hyp & Asteraceae & Shrub & Lad \\
\hline Ehretia anacua (Mier y Berland) I. M. Johnst & Ehr ana & Boraginaceae & Shrub & $\mathrm{Di}$ \\
\hline Cordia boissieri A. DC. & Cor boi & Boraginaceae & Small tree & Di, De, Lad, Mes \\
\hline Diospyros texana Scheele & Dio tex & Ebenaceae & Small tree & Di, De, Val, Lad \\
\hline Croton cortesianus Kunth & Cro cor & Euphorbiaceae & Shrub & Di, Val \\
\hline Croton torreyanus Muell. Arg. & Cro tor & Euphorbiaceae & Shrub & De \\
\hline Bernardia myricaefolia (Scheele) S. Watson & Ber myr & Euphorbiaceae & Shrub & Di, De, Val \\
\hline Krameria lanceolata Torr. & Kra lan & Krameriaceae & Herbacous & Lad, Mes \\
\hline Zapoteca media (M. Martens and Galeotti) H. Hern. & Zap med & Leguminosae & Shrub & Val, Lad \\
\hline Eysenhardtia texana Scheele & Eys tex & Leguminosae & Shrub & De, Lad, Mes \\
\hline Havardia pallens (Benth.) Briton and Rose & Hav pal & Leguminosae & Small tree & Di, De, Val \\
\hline Mimosa malacophylla A. Gray & Mim mal & Leguminosae & Liana & Di, De \\
\hline Prosopis laevigata (Willd.) M. C. Johnst. & Pro lae & Leguminosae & Small tree & Di \\
\hline Calliandra conferta A.Gray & Cal con & Leguminosae & Shrub & Mes \\
\hline Acacia wrightii Benth. & Aca wri & Leguminosae & Small tree & De \\
\hline Acacia rigidula Benth. & Aca rig & Leguminosae & Shrub & De, Val, Lad, Mes \\
\hline Acacia berlandieri Benth & Aca ber & Leguminosae & Shrub & Lad, Mes \\
\hline Fraxinus greggii A. Gray & Fra gre & Oleaceae & Shrub & Di \\
\hline Forestiera angustifolia Torr. & For ang & Oleaceae & Shrub & Di, De, Val \\
\hline Condalia hookeri M. C. Johnst. & Con hoo & Rhamnaceae & Small tree & Di, Val \\
\hline Karwinskia humboldtiana (R. and S.) Zucc. & Kar hum & Rhamnaceae & Shrub & Di, De, Val, Mes \\
\hline Randia laetevirens Standl. & Ran lae & Rubiaceae & Shrub & Di, De \\
\hline Amyris texana (Buckl.) P. Wilson & Amy tex & Rutaceae & Shrub & $\mathrm{Di}, \mathrm{De}$ \\
\hline Amyris madrensis S. Watson & Amy mad & Rutaceae & Shrub & Di \\
\hline Zanthoxylum fagara (L.) Sarg. & Zan fag & Rutaceae & Shrub & Di, Val, Lad \\
\hline Helietta parvifolia (Gray) Benth. & Hel par & Rutaceae & Shrub & Mes \\
\hline Sideroxylon lanuginosum Michaux & Sid lan & Sapotaceae & Shrub & Di, Val \\
\hline Sideroxylon celastrinum (Kunth) & Sid cel & Sapotaceae & Shrub & De \\
\hline Leucophyllum frutescens (Berl.) I. M. Johnst. & Leu fru & Scrophulariaceae & Shrub & Mes \\
\hline Lycium berlandieri Dun var. Berlandieri & Lyc ver & Solanaceae & Shrub & De, \\
\hline Turnera diffusa Willd. var aphrodisiaca (Ward) Urban & Tur dif & Turneraceae & Shrub & Lad, Mes \\
\hline Celtis pallida Torr. & Cel pal & Ulmaceae & Shrub & Di \\
\hline Celtis laevigata Wild. & Cel lae & Ulmaceae & Árbol & $\mathrm{Di}$ \\
\hline Lantana macropoda Torr. & Lan mac & Verbenaceae & Shrub & Lad \\
\hline Lippia graveolens H. B. K. & Lip gra & Verbenaceae & Small tree & $\mathrm{La}$ \\
\hline
\end{tabular}

De: ephemeral floodplain; Di: intermittent floodplain; Val: Valley; Lad: slopes; Mes: mesa or plateau.

floodplains, with means and standard deviations of $(\bar{x}=7 \pm 2)$ in the plateau, $(\bar{x}=7 \pm 1)$ in the slopes, $(\bar{x}=6 \pm 1)$ in the valley, $(\bar{x}=7 \pm 3)$ in the ephemeral floodplain, and $(\bar{x}=10 \pm 2)$ in the intermittent floodplain. The total number of species in all three sites per landform also increased from the plateau (7) to the intermittent floodplain (18).

The total number of species increased nonlinearly as a function of productivity. However this relationship fitted an opposite nonlinear trend for the mature stages of succession. Total aboveground biomass and stand density increased from dry to riparian plots and so did mean basal diameter and mean top height but only for the mature succession stages (Table 2).

The correlation matrices for early (Table 3(a)) and late (Table 3(b)) successional stages between productivity, diversity, and environmental variables show $S$ is better and statistically related to $\mathrm{N}$ in the early as well as to NPP, Text, and CN ratio for late successional stages. NPP is statistically related to Text and CN ratio for both early and late successional stages.

Species diversity was high in the early succession stage, in contrast to the species diversity present at the time of harvesting vegetation along the topographic gradient (Figure 1; 
TABLE 2: The mean spatio-temporal variations of diversity and abundance of species along a productivity gradient in the Tamaulipan thornscrub of northeastern Mexico.

\begin{tabular}{lcccccccccc}
\hline \multirow{2}{*}{ Landform } & \multicolumn{2}{c}{$\mathrm{TAB}\left(\mathrm{Mg} \mathrm{ha}^{-1}\right)$} & \multicolumn{2}{c}{$N\left(\mathrm{Noha}^{-1}\right)$} & \multicolumn{2}{c}{$H(\mathrm{~m})$} & \multicolumn{2}{c}{$D(\mathrm{~cm})$} & \multicolumn{2}{c}{$S(\mathrm{No})$} \\
& $\mathrm{L}$ & $\mathrm{E}$ & $\mathrm{L}$ & $\mathrm{E}$ & $\mathrm{L}$ & $\mathrm{E}$ & $\mathrm{L}$ & $\mathrm{E}$ & $\mathrm{L}$ & $\mathrm{E}$ \\
\hline Floodplain & 80 & 2.1 & 3700 & 22000 & 5.1 & 0.66 & 5.3 & 0.92 & 3 & 18 \\
EFP & 76 & 2.6 & 4100 & 62000 & 4.4 & 0.61 & 3.6 & 0.92 & 3 & 15 \\
Valley & 47 & 2.7 & 4900 & 48000 & 4.0 & 0.50 & 4.2 & 0.71 & 3 & 17 \\
Slope & 11 & 1.4 & 5000 & 75000 & 2.0 & 0.41 & 2.8 & 0.42 & 5 & 12 \\
Plateau & 9 & 0.8 & 6700 & 52000 & 1.4 & 0.68 & 2.4 & 0.89 & 6 & 7 \\
\hline
\end{tabular}

Floodplain: intermittent floodplain; EFP: ephemeral floodplain; TAB: total aboveground biomass; $N$ : number of individuals or stand density; $H$ : total height; $D$ : basal diameter; $S$ : species richness; L: late; E: early successional stages.

see nomenclature of Table 1). After one year of postclearing growth, the relative portion of perennials (sprouts) and ephemerals (seedlings) can be attributed to the form of reproduction and to the different survival strategies of these life forms.

The species Amyris madrensis, Amyris texana, Havardia pallens, Bernardia myricaefolia, Condalia hookeri, Randia laetevirens, Sideroxylum langinosum, Forestiera angustifolia, Celtis pallida, Fraxinus greggi, Ehretia anacua, and Celtis laevigata are characteristic of the most productive sites (intermittent and ephemeral floodplains), whereas Lippia graveolens, Acacia rigidula, Acacia berlandieri, Calliandra conferta, Turnera diffusa, Krameria lanceolata, Helietta parvifolia, and Leucophyllum frutescens are typical shrub species found in low productivity and semi-arid sites.

In general, the most productive mature sites have a mean of only nine established shrub species. In the early stages of succession, mean species richness per plot increased to 25 species. This represents a species loss of $74 \%$ from the early stage to the late succession stage (9/25). In contrast, in the least productive landforms, the number of species present before harvesting consisted of a mean of 13 species, whereas in the early phases of succession, 20 species appeared during the course of one year. The rate of species loss in these sites was only $35 \%(13 / 20)$. These results suggest that the rate of local extinction is higher in the most productive sites, twice as high as that in the least productive sites. The differential growth rhythms and forms of germination provide a competitive advantage to tall species and species with asexual reproduction since these species provide strong competition for light and soil water in the early stages.

Seedling density in early succession is ten times greater than shrub density in the late stages of succession. Average seedling density one year after harvesting shrubs was 52,425 seedlings $\mathrm{ha}^{-1}$, whereas before harvesting, shrub density averaged $4,900 \mathrm{ha}^{-1}$. These dramatic changes are due to the fact that shrubs grow over time, attaining larger dimensions and displacing or shading other shrubs by overcrowding. The $3 / 2$ thinning law may operate at both intra- and inter-specific levels allowing competition to modulate both stand density and diversity. Intra- and inter-specific competition can cause mortality in individuals of the same species and individuals of different species with similar adaptive strategies. Mortality or species exclusion by factors associated with inter-specific
TABLE 3: Correlation matrices for early and late successional stages between productivity, diversity, and environmental variables in Tamaulipan thorn scrub forests of northeastern Mexico.

(a)

\begin{tabular}{lccccccc}
\hline & $S$ & Den & $\mathrm{N}$ & NPP & Text & OM & CC \\
\hline \multirow{2}{*}{ Den } & -0.30 & & & & & & \\
& 0.27 & & & & & & \\
N & 0.48 & 0.07 & & & & & \\
& 0.07 & 0.77 & & & & & \\
& 0.35 & -0.08 & 0.46 & & & & \\
NPP & 0.20 & 0.76 & 0.08 & & & & \\
& 0.14 & -0.56 & 0.11 & 0.65 & & & \\
Text & 0.61 & 0.02 & 0.71 & 0.00 & & & \\
& -0.08 & 0.46 & 0.43 & -0.28 & -0.70 & & \\
OM & 0.77 & 0.08 & 0.10 & 0.30 & 0.00 & & \\
& -0.08 & 0.46 & 0.43 & -0.28 & -0.70 & 1.00 & \\
CC & 0.77 & 0.08 & 0.10 & 0.30 & 0.00 & 0.00 & \\
& -0.38 & 0.36 & 0.37 & -0.66 & -0.81 & 0.64 & 0.64 \\
CN & 0.15 & 0.18 & 0.18 & 0.00 & 0.00 & 0.00 & 0.00 \\
\hline
\end{tabular}

(b)

\begin{tabular}{cccccccc}
\hline & $S$ & Den & $\mathrm{N}$ & NPP & Text & OM & CC \\
\hline \multirow{2}{*}{ Den } & 0.62 & & & & & & \\
& 0.01 & & & & & & \\
$\mathrm{~N}$ & -0.31 & -0.27 & & & & & \\
& 0.26 & 0.33 & & & & & \\
NPP & -0.51 & -0.42 & 0.29 & & & & \\
& 0.01 & 0.11 & 0.30 & & & & \\
Text & -0.69 & -0.27 & 0.11 & 0.63 & & & \\
& 0.00 & 0.33 & 0.71 & 0.00 & & & \\
OM & 0.24 & 0.05 & 0.43 & -0.46 & -0.70 & & \\
& 0.38 & 0.83 & 0.10 & 0.08 & 0.00 & & \\
CC & 0.24 & 0.05 & 0.43 & -0.46 & -0.70 & 1.00 & \\
& 0.39 & 0.84 & 0.10 & 0.08 & 0.00 & 0.00 & \\
CN & 0.55 & 0.34 & 0.39 & -0.71 & -0.81 & 0.64 & 0.64 \\
& 0.03 & 0.21 & 0.15 & 0.00 & 0.00 & 0.00 & 0.00 \\
\hline
\end{tabular}

S: species richness; Den: density (number of individuals per hectare); $\mathrm{N}$ : soil nitrogen content; NPP: productivity; Text: texture; OM: soil organic matter content; CC: soil carbon content; $\mathrm{CN}$ : $\mathrm{C} / \mathrm{N}$ ratio. 

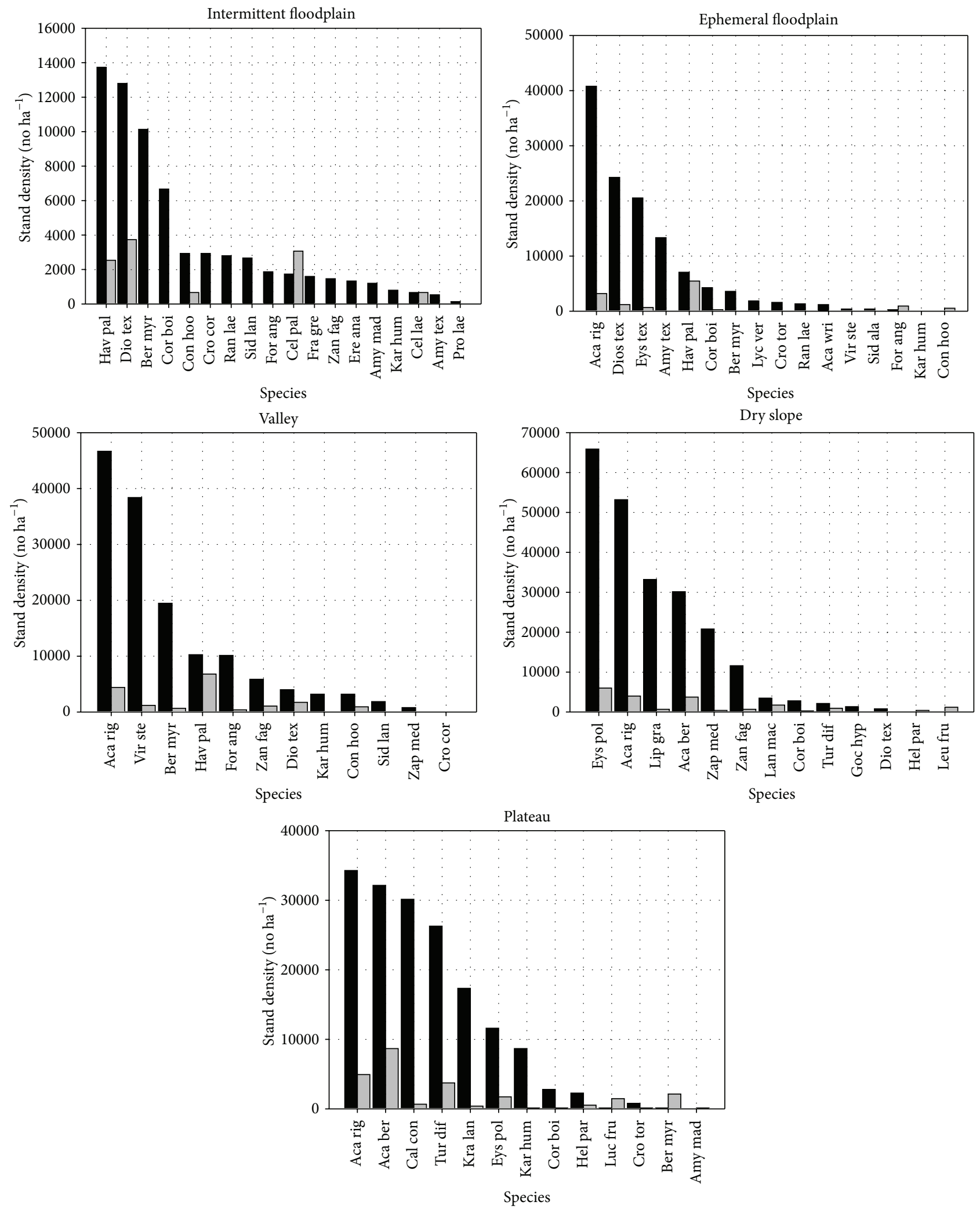

Pioneer stages
$\square$ Late stages

FIGURE 1: Diversity-abundance of species in pioneer and late succession stages in the Tamaulipan thornscrub in northeast Mexico. 
TABLE 4: Values of soil variables in fifteen sampling sites of the Tamaulipan thornscrub forest.

\begin{tabular}{lccccc}
\hline S-P & Texture & O.M. (\%) & C. C. $(\%)$ & N (\%) & C/N \\
\hline 11 & 46.00 & 7.09 & 4.11 & 0.14 & 28.68 \\
12 & 43.00 & 5.50 & 3.19 & 0.12 & 26.03 \\
13 & 34.98 & 9.40 & 5.45 & 0.15 & 36.21 \\
21 & 37.03 & 5.91 & 3.43 & 0.11 & 31.08 \\
22 & 37.95 & 8.08 & 4.68 & 0.14 & 32.94 \\
23 & 42.95 & 8.27 & 4.80 & 0.12 & 39.86 \\
31 & 45.95 & 5.25 & 3.04 & 0.08 & 39.68 \\
32 & 41.00 & 5.72 & 3.32 & 0.13 & 25.99 \\
33 & 40.98 & 8.47 & 4.91 & 0.10 & 51.28 \\
41 & 10.03 & 16.39 & 9.51 & 0.17 & 56.38 \\
42 & 14.03 & 15.76 & 9.14 & 0.15 & 61.15 \\
43 & 11.50 & 19.21 & 11.14 & 0.11 & 104.72 \\
51 & 16.00 & 12.23 & 7.09 & 0.07 & 95.22 \\
52 & 21.98 & 4.28 & 2.48 & 0.04 & 62.37 \\
53 & 20.05 & 4.69 & 2.72 & 0.04 & 64.79 \\
\hline
\end{tabular}

S-P: quadrat; O.M.: content of organic matter; C. C.: content of organic carbon; N: content of nitrogen; $\mathrm{C} / \mathrm{N}$ : ratio of carbon to nitrogen content.

competition must also be present, but discussing the mechanisms that cause this requires more frequent measurements between the different stages of succession. Additional data is also required in order to develop or to fit available models of succession [5].

The stocking reduction is less variable than species exclusion across the productivity gradient. The average survival rate (confidence interval) defined as $(1-[(N-n) / N]) * 100$ (where $N=$ seedling density; $n=$ shrub density) is $11 \%$ (4\%), and this is weakly related to stand productivity. That is, the mortality of individuals in the transition is high and somehow related, but with a small mean survival range across productivity levels (from $13 \%$ in high to $8 \%$ in low productivity sites, resp.). Shrub survival rate is higher in the least dense stands and lower in the densest stands. High productivity sites have smaller initial and final stand densities with higher survival rates. The inverse is true for plateaus and dry sites.

The soil variables display high dispersion for the different measures of productivity. At the plateau and slope sites, the texture is sandy-silty-clayey, with contrasting organic matter and nitrogen contents, while the mean organic matter content remains quite stable between productivity sites; the average soil nitrogen content is high (14\%) in high and small (5\%) in low productivity sites. The amount of organic matter and nitrogen is similar to that of the valley and intermittent floodplain and generally greater than those of the plateau; nevertheless, the soil textures are different, being clay-silty-sandy and clayey-silty, respectively. The ephemeral floodplain presents a clayey texture, with medium organic matter and organic carbon contents and the highest values of soil nitrogen (Table 4).

Aboveground NPP during the first year of regrowth correlates with total aboveground biomass in late succession

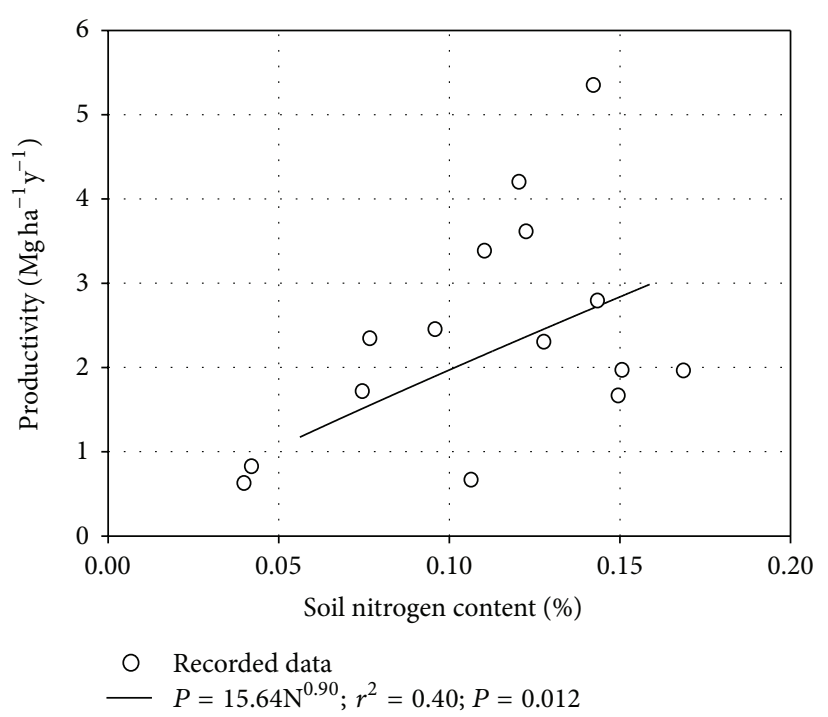

FIGURE 2: The relationship between aboveground productivity and soil nitrogen content in the Tamaulipan thornscrub forests of northeastern Mexico.

across all landforms, with a tendency for increased aboveground biomass from the plateau toward the floodplains. This suggests that annual NPP can be estimated on the basis of late-successional biomass, using the equation: productivity $=$ $0.85+0.034$ total aboveground biomass; $r^{2}=0.78 ; n=15$.

Productivity across plots varies from 0.62 to $5.35 \mathrm{Mg} \mathrm{ha}^{-1}$ year $^{-1}$, with an average $\bar{x}$ of $2.39 \mathrm{Mg} \mathrm{ha}^{-1}$ year $^{-1}$ and a standard deviation of $1.32 \mathrm{Mg} \mathrm{ha}^{-1}$ year $^{-1}$ (Figure 2). It tends to increase from the plateau toward the floodplains almost linearly with aboveground biomass stocks.

The soil nitrogen-productivity relationship fits better a power-law $\left(r^{2}=0.39 ; P=0.012\right)$ than a linear $\left(r^{2}=0.21\right.$; $P=0.08)$ equation, although an $F$-test provided insufficient evidence $(F=0.18 ; P=0.84)$ that the power-law model is statistically different from the linear model. Therefore, the productivity rate increases monotonically with soil nitrogen content (Figure 2). The classic triangular distribution has an upper boundary given by $3 \mathrm{Mg} \mathrm{ha}^{-1} \mathrm{y}^{-1}$ and $0.15 \%$ of soil nitrogen content. Other limiting elements, such as soil carbon content, soil water content, and sunlight must control the lower aboveground productivity.

Aboveground biomass and soil organic carbon content fitted a negative linear relationship (TAB $=81-7 \mathrm{CC} ; r^{2}=$ $0.22)$. Aboveground biomass productivity is a log-normal function of the soil carbon/nitrogen $(\mathrm{CN})$ ratio $(P=0.017)$ (Figure 3). Low $\mathrm{CN}$ ratios are associated with high availability of mineral nitrogen, which is the form available to plants. In sites with reduced aboveground biomass productivity, soil nitrogen content seems to be the limiting factor. The $\mathrm{CN}$ ratio has a large effect on the microbial processes that regulate $\mathrm{N}$ availability in the soil. This effect is typical in sites of a low accumulation of organic matter as the carbon source, such as in the plateaus of the Coastal Plain of the northern Gulf of Mexico. A lack of other minerals appears to be 


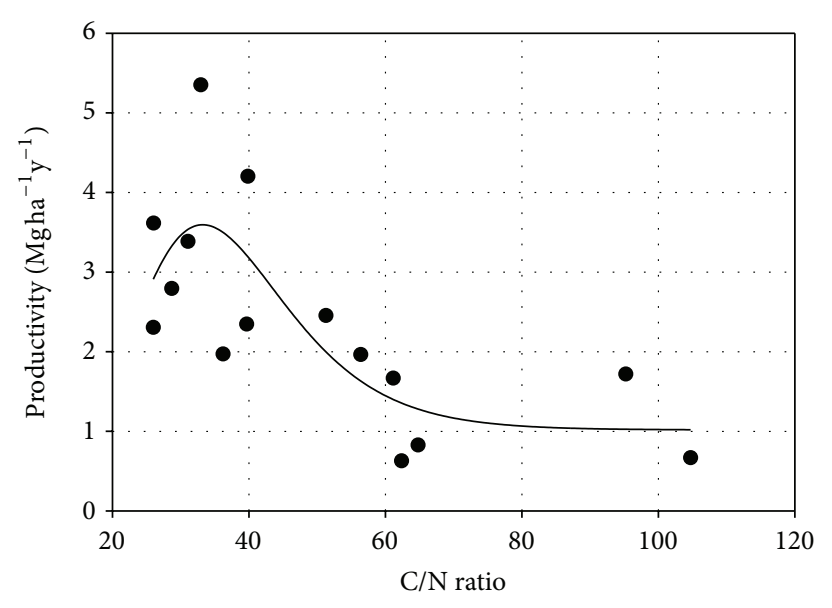

- Recorded data

$P(\mathrm{CN})=1.017+2.578 e^{\left(-0.5^{*}((\ln (\mathrm{CN} / 33.22)) / 0.31)^{2}\right)} r^{2}=0.59$

FIGURE 3: The relationship between aboveground productivity and $\mathrm{C} / \mathrm{N}$ ratio for five geoforms established in the Tamaulipan thornscrub forests of northeastern Mexico.

the limiting factor at sites of high organic matter accumulation in plots established in the high productivity intermittent and ephemeral floodplains where decomposition rates are high in warm moist environments with low $\mathrm{CN}$ ratios of the plant material.

Shrub diversity shows a positive linear relationship to soil nitrogen content in the pioneer stages of succession (Figure 4). Unsurprisingly, the proportion of leguminous species is smaller at sites with high soil nitrogen content, like floodplains (5\%) than at sites with low soil nitrogen content, such as the slopes and mesas (11\%).

The relationship of soil nitrogen to species richness shifts from positive to negative between the early and late successional stages (Figure 4). That is, diversity diminishes monotonically with increasing soil nitrogen content. Soils of the harvested sites remained undisturbed (by, e.g., plowing, trampling, or grazing) during the one-year period of plant regrowth; therefore, soil organic content remained quite constant throughout the study period. This partially explains the increase in seedling diversity with increasing soil nitrogen in the pioneering stages, in contrast to the shrub diversity in the later stages of succession, during which shrub diversity decreased with increasing soil nitrogen content.

The diversity of shrubby species is also negatively related in a power fashion to the carbon/nitrogen ratio, although this relationship is not statistically significant $(P=0.12)$. Shrub diversity and calculated aboveground productivity are significantly related through monotonic models. That is, no humpback patterns fit the data of the late stages of succession in the Tamaulipan thornscrub plant community for measured as well as modeled data (Figure 5). Shrub diversity diminishes incrementally with increasing aboveground biomass productivity. This finding is consistent with the reduced shrub diversity in highly productive gradients demonstrated above.

The hypothesis of diversity reduction by the stochastic mortality of shrub species due to self-thinning was tested

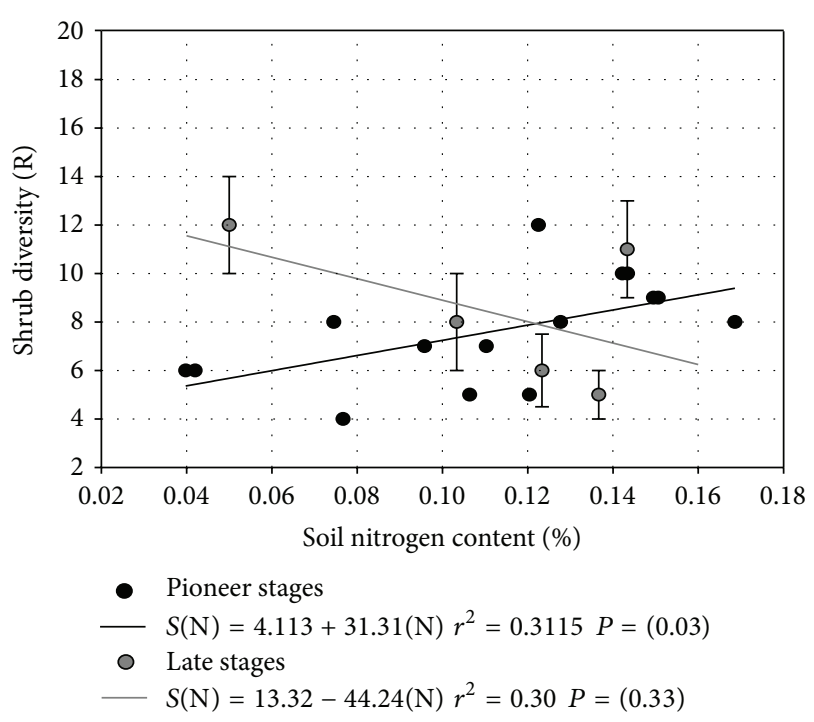

FIGURE 4: The relationships between shrub diversity and soil nitrogen content in the Tamaulipan thornscrub forests of northeastern Mexico.

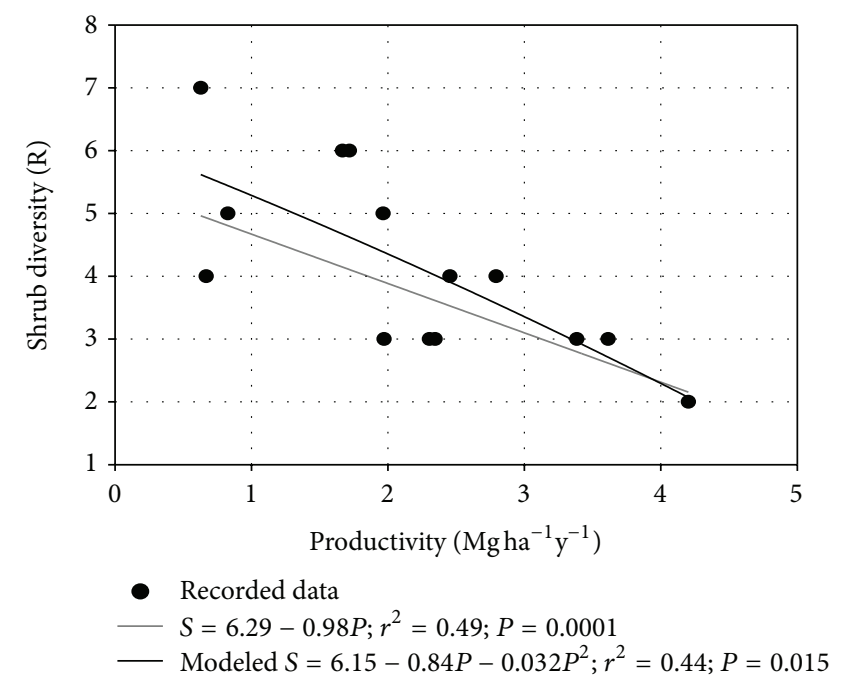

FIgURE 5: The relationships between measured and modeled shrub species richness for late successional stages and measured aboveground biomass productivity for the Tamaulipan thornscrub forests of northeastern Mexico.

using the statistical relationships between density and productivity and diversity and density for the primary and late stages of succession (Models 2 and 3). These relationships were not statistically significant in the early stages; only the second relationship displayed statistical significance in mature scrublands. Therefore, the exclusion of shrub species by stochastic mortality explained less than $11 \%$ of the total $S$ variation and therefore the hypothesis of self-thinning for the plant community was not supported by data from the Tamaulipan thornscrub community. 


\section{Discussion}

Our average estimate of aboveground NPP in the early stages of succession $2.39( \pm 1.32) \mathrm{Mg} \mathrm{ha}^{-1} \mathrm{a}^{-1}$ is higher than the mean current annual productivity for Tamaulipan thornscrub forests of northeastern Mexico reported by Návar et al. [26] of $1.61 \mathrm{Mg} \mathrm{ha}^{-1} \mathrm{a}^{-1}$. Higher productivity values during the early phases of succession are consistent with the theory of highest growth rates during the initial stages of succession in most plant populations or communities $[27,28]$.

Neither the monotonic $(P=0.17)$ nor the humpback $(P=0.39)$ models fit the relationship between diversity and productivity in the early or mature stages of succession. The monotonic model shows significant changes in diversity with increasing productivity. The relationship between shrub diversity and aboveground biomass productivity differs in the early and late stages of succession. In the former, the relationship is positive, whereas in the latter stages, the relation is negative. Note that this shift is predicted by Smith and Huston [29] and discussed in detail by Huston [5]. Both theoretical models of plant competition and applied models of plant growth and competition predict that the pattern of diversity in relation to productivity reverses between early and late succession. This is a general result and should be found in nearly all vegetation types. This finding requires more information to test the hypothesis of unimodality; however, it does show that there is no single relationship that describes the diversity-productivity of the Tamaulipan thornscrub plant community at all successional stages. It is more likely that this relationship differs between the different succession stages of plant communities. These observations have been predicted earlier by several authors $[5,13,29]$.

No species was found in all sites at both stages of succession. Only four and two species distributed in four sites and most species (17 and 6) were found in one single site for early and mature stages of succession, respectively. The number of species occupying different sites coalesces in 5 species distributing at three specific sites. The distribution of widespread species along this gradient fit a linear $(y=$ $\left.19.7-4.1 x ; r^{2}=0.95\right)$ and a second-degree polynomial $(y=$ $\left.5.6+0.6429 x-0.36 x^{2} ; r^{2}=0.96\right)$ adjusted the relationship between the number of species $(y)$ distributing along sites $(x)$ for early and mature successional stages. The potential or physiological niche (e.g., [13]) and ecological niche converge at 2 species (D. texana and C. boissieri, in the early and $H$. pallens and A. rigidula in the mature stages of succession) distributed across four sites.

The model defining diversity versus productivity in the late stages of succession with stochastic species exclusion explained only $11 \%$ of the total variation in shrub species diversity, but showed a tendency toward reduced shrub diversity as aboveground biomass productivity increased. This information is consistent with the models by Grime [6] and Stevens and Carson $[11,14]$ that emphasize deterministic mortality caused by similitude in competitive ability of species to establish and last through the mature stages of succession. Therefore, it can be concluded that in the Tamaulipan thornscrub community, the rate of change of shrub species seems to only partially follow the mortality by stochastic processes that happen in monocultures fitting the 3/2 law of thinning. It is more likely that the mechanisms of intraand inter-specific density dependence are simultaneously operating with a differential magnitude in different life stages and modified by disturbances (e.g., growth and droughts, among others). This seems to be due to the fact that interspecific competition, although it begins in the early stages of succession, is still not as important as the processes of adaptation to environmental conditions that prevails on-site. Mortality by nonrandom processes also plays an important role and can explain the rest of the variation in the model of mortality by demography in the late stages of succession. As the species develop in dimensions and density is extremely high, both intra- and inter-specific competition reduce the number of individuals and seem to reduce the number of species as the succession advances as well. The inter-specific competition gradient moves from the plateau to the riparian community, with quasi null competition in dry and strong inter-specific competition in riparian places.

The range from a low species survival rate of $36 \%$ in highly productive environments to a high of $65 \%$ in low productive environments suggests that inter-specific competition is stronger in more productive landscapes and less pronounced in less productive sites in the Tamaulipan thornscrub forests. In fact, the relationship between species survival and aboveground biomass productivity was negatively and highly significant $\left(\mathrm{SR}=4.7-4.1(\mathrm{P}) ; r^{2}=0.62\right.$; $n=15 ; P=0.0001)$ where SR is rate of species survival (number of species in late/number of species in early stages of succession) and $\mathrm{P}$ is productivity $\left(\mathrm{Mgha}^{-1} \mathrm{y}^{-1}\right)$. The rate of species exclusion is $100-\mathrm{SR}$. Although a similar relationship was observed between rate of species survival and soil nitrogen content, it was not statistically significant. That is, all abiotic factors that control productivity, but in particular soil nitrogen content, should be considered stressors, given by the deficiency of resources. These findings are partially consistent with theoretical models that have predicted the relative importance of facilitation, and competition will vary inversely across gradients of abiotic stress, with facilitation being the dominant interaction under high abiotic stress conditions [30, 31].

Stand density is reduced more homogeneously than species diversity along the productivity gradient, with values ranging between 6 and 16\% for the pioneer to the late succession stages. However, stand density is not related to stand aboveground biomass productivity, but only to aboveground biomass, which is the long term sum of the productivity. Since species exclusion is less pronounced in low productivity sites, intra-specific competition is more acute in high abiotic stress gradients since stand density survival reduces in a negative power fashion with productivity. In other words, intra-specific density dependence plays an important role in higher abiotic stress gradients or it could be simply abiotic stress with no intra-specific interactions. It appears that a combination of both intra- and inter-specific density dependence is more important in more productive areas. The former may be explained by the temporal and spatial overlap 
in the use of limited resources of individuals of the same species.

In late succession stages, shrub diversity is higher in less productive sites and so must be the variety of survival mechanisms they use during development. This can be explained by the variety of strategies they use in the temporal and spatial exploitation of limited resources (soil water and fertility). Stable coexistence in harsh and variable environments requires mechanisms that distinguish species ecologically, which may be a contrast to Huston's [13] findings (such differences are more important in stable productive environments and less important in harsh and variable environments). This is a prerequisite for intra-specific density dependence to be stronger than inter-specific density dependence. In high productivity landscapes or environments with lower abiotic stress this is an issue primarily in equilibrium competition analysis such as Lotka-Volterra models or Tilmans $\mathrm{R}^{*}$ models [13]. Under nonequilibrium conditions, disturbances and environmental variability interrupt the process of competitive exclusion, such as disturbances on the intermittent and ephemeral floodplains. Intra- and inter-specific competition are better balanced under average site conditions since species exclusion reaches $36 \%$ and self-thinning mechanisms achieve above $16 \%$ of the original stand density in early successional stages.

Finally, both negative interactions (e.g., competition, [6, $7,13,32]$ ) and positive interactions (e.g., facilitation, $[13,30$, $33,34])$ are likely to be present in this plant community. These occur simultaneously, but their dominance depends on the successional stage of development of the plant community. The relative dominance of these interactions must control the relationship between species diversity and productivity. This is a matter for further research.

\section{Conclusions}

Tree diversity changes in both space and time. In pioneering succession stages it declines from the high to the low productivity gradients but it reverses in the late phases of succession. The rate of species survival increases from $36 \%$ in the transition from the pioneering to the late stages in highly productive gradients to $65 \%$ in low productivity environments. Stem density is also greater in the pioneering rather than the late stages of succession. The mortality of individuals and species by a variety and magnitude of processes is important in this plant community. After this short period of study, the colonization and permanence of species are attributable to several factors, within which intra- and interspecific competition and facilitation are factors that modulate the exclusion and coexistence of individuals and species. This quantitative evidence suggests that inter-specific competition is more pronounced in more productive sites than in less productive sites, although fewer shrub species colonize the latter due to low productivity levels in the early stages of succession. Stochastic mortality explained less than $11 \%$ of the species exclusion. It seems that the deterministic mechanisms related to competitive exclusion where there are similarities in the use of resources, physiology, and exploitation of soil and light, among others, can overlap between several species in productive sites and that this similarity vanishes partially over time in less productive sites. It is also likely that abiotic stress may be related to species mortality. Further research is required in order to further understand the mechanisms of species exclusion and coexistence.

\section{Conflict of Interests}

The authors have no conflict of interests to declare.

\section{Acknowledgments}

The authors of this report thank Raul Bretado and Maricela Peña for their help with data collection. We also thank the numerous reviewers who improved the scientific understanding and readability of this manuscript. The Instituto Politécnico Nacional authors are COFAA-IPN scholars.

\section{References}

[1] G. G. Mittelbach, C. F. Steiner, S. M. Scheiner et al., "What is the observed relationship between species richness and productivity?" Ecology, vol. 82, no. 9, pp. 2381-2396, 2001.

[2] B. A. Hawkins, R. Field, H. V. Cornell et al., "Energy, water, and broad-scale geographic patterns of species richness," Ecology, vol. 84, no. 12, pp. 3105-3117, 2003.

[3] S. L. Shafer, P. J. Bartlein, and R. S. Thompson, "Potential changes in the distributions of Western North America tree and shrub taxa under future climate scenarios," Ecosystems, vol. 4, no. 3, pp. 200-215, 2001.

[4] D. A. Clark, S. Brown, D. W. Kicklighter, J. Q. Chambers, J. R. Thomlinson, and J. Ni, "Measuring net primary production in forests: concepts and field methods," Ecological Applications, vol. 11, no. 2, pp. 356-370, 2001.

[5] M. A. Huston, Biological Diversity, Cambridge University Press, Cambridge, UK, 1994.

[6] J. P. Grime, "Control of species diversity in herbaceous vegetation," Journal of Environmental Management, vol. 1, pp. 151-167, 1973.

[7] J. P. Grime, Plant Strategies and Vegetation Processes, John Wiley \& Sons, New York, NY, USA, 1979.

[8] P. A. Abrams, "Monotonic or unimodal diversity-productivity gradients: what does competition theory predict?" Ecology, vol. 76, no. 7, pp. 2019-2027, 1995.

[9] M. L. Rosenzweig, Species Diversity in Space and Time, Cambridge University Press, Cambridge, UK, 1995.

[10] R. B. Waide, M. R. Willig, C. F. Steiner et al., "The relationship between productivity and species richness," Annual Review of Ecology and Systematics, vol. 30, pp. 257-300, 1999.

[11] M. H. H. Stevens and W. P. Carson, "Plant density determines species richness along an experimental fertility gradient," Ecology, vol. 80, no. 2, pp. 455-465, 1999.

[12] Q. Guo and P. W. Rundel, "Self-thinning in early postfire chaparral succession: mechanisms, implications, and a combined approach," Ecology, vol. 79, no. 2, pp. 579-586, 1998.

[13] M. A. Huston, "Management strategies for plant invasions: manipulating productivity, disturbance, and competition," Diversity and Distributions, vol. 10, no. 3, pp. 167-178, 2004. 
[14] M. Henry, H. Stevens, and W. P. Carson, "The significance of assemblage-level thinning for species richness," Journal of Ecology, vol. 87, no. 3, pp. 490-502, 1999.

[15] N. Reid, D. M. Stafford Smith, P. Beyer-Munzel, and J. Marroquín, "Floristic and structural variation in the Tamaulipan thornscrub, northeastern Mexico," Journal of Vegetation Science, vol. 1, pp. 529-538, 1990.

[16] J. D. J. Návar-Chaidez, "Carbon fluxes resulting from land-use changes in the Tamaulipan thornscrub of northeastern Mexico," Carbon Balance and Management, vol. 3, article 6, 2008.

[17] J. Návar and T. Synnott, "Soil erosion and land use in northeastern México," Terra, vol. 18, no. 3, pp. 247-253, 2000.

[18] J. Návar and T. Synnott, "Soil infiltration and land use in northeastern México," Terra, vol. 18, no. 3, pp. 255-262, 2000.

[19] G. Villegas, Tipos de vegetación de los municipios de Linares y Hualahuises [N. L. Tesis de licenciatura], Escuela de Agricultura, UAG, 1972.

[20] C. M. G. Manzano, "Programa de restauración ecológica integral en la Zona II de la Cuenca de Burgos," Proyecto CJ070, ITESM. Centro de Calidad Ambiental. Informe Final. SNIBCONABIO, Mexico City, Mexico, 2006.

[21] E. Treviño, A. Akca, J. Návar, J. Jimenez, and O. Aguirre, "Detection of land use change by satellite imagery in the municipality of Linares," in Proceedings of the 5th International Conference on Desert Development, vol. I, Texas Tech University, Nuevo Leon, Mexico, August 1996.

[22] J. Návar, T. Cavazos, and P. A. Domínguez, "Los balances hidrológicos mensuales con tres probabilidades de precipitación en el estado de Nuevo León," in Actas de la Facultad de Ciencias de la Tierra UANL, S. Pola, J. A. Ramírez, M. M. Rangel, and I. Navarro, Eds., vol. 8, pp. 71-82, Linares, Spain, 1994.

[23] J. Návar, D. E. Carlyle-Moses, and M. Alfonso Martinez, "Interception loss from the Tamaulipan matorral thornscrub of north-eastern Mexico: an application of the Gash analytical interception loss model," Journal of Arid Environments, vol. 41, no. 1, pp. 1-10, 1999.

[24] M. Woerner, "Los suelos bajo vegetación de matorral del noreste de México, descritos a través de ejemplos en el campus universitario de la UANL, Linares," N. L. Reporte Científico 22, Facultad de Ciencias Forestales, Linares, Mexico, 1991.

[25] C. A. E. Estrada and J. S. Marroquín, "Leguminosas de Nuevo León I. Sinopsis de las especies de Linares,” Reporte Científico 9, Facultad de Ciencias Forestales, UANL, Linares, Mexico, 1988.

[26] J. Návar, J. Nájera, and E. Jurado, "Preliminary estimates of biomass growth in the Tamaulipan thornscrub in north-eastern Mexico," Journal of Arid Environments, vol. 47, no. 3, pp. 281290, 2001.

[27] J. L. Clutter, J. C. Forston, L. V. Pienaar, G. H. Brister, and R. I. Bailey, Timber Management: A Quantitative Approach, John Wiley \& Sons, Nueva York, NY, USA, 1983.

[28] R. H. Whittaker, "Evolution of species diversity in land communities," Journal of Evolutionary Biology, vol. 10, pp. 1-67, 1985.

[29] T. A. Smith and M. A. Huston, "A theory of the spatial and temporal dynamics of plant communities," Vegetatio, vol. 83, no. 1-2, pp. 49-69, 1989.

[30] M. Holmgren, M. Scheffer, and M. A. Huston, "The interplay of facilitation and competition in plant communities," Ecology, vol. 78, no. 7, pp. 1966-1975, 1997.

[31] F. T. Maestre, F. Valladares, and J. F. Reynolds, "Is the change of plant-plant interactions with abiotic stress predictable? A metaanalysis of field results in arid environments," Journal of Ecology, vol. 93, no. 4, pp. 748-757, 2005.
[32] P. A. Keddy, Competition, Chapman \& Hall, London, UK, 1989.

[33] R. M. Callaway, R. W. Brooker, P. Choler et al., "Positive interactions among alpine plants increase with stress," Nature, vol. 417, no. 6891, pp. 844-848, 2002.

[34] J. F. Bruno, J. J. Stachowicz, and M. D. Bertness, "Inclusion of facilitation into ecological theory," Trends in Ecology \& Evolution, vol. 18, pp. 119-125, 2003. 

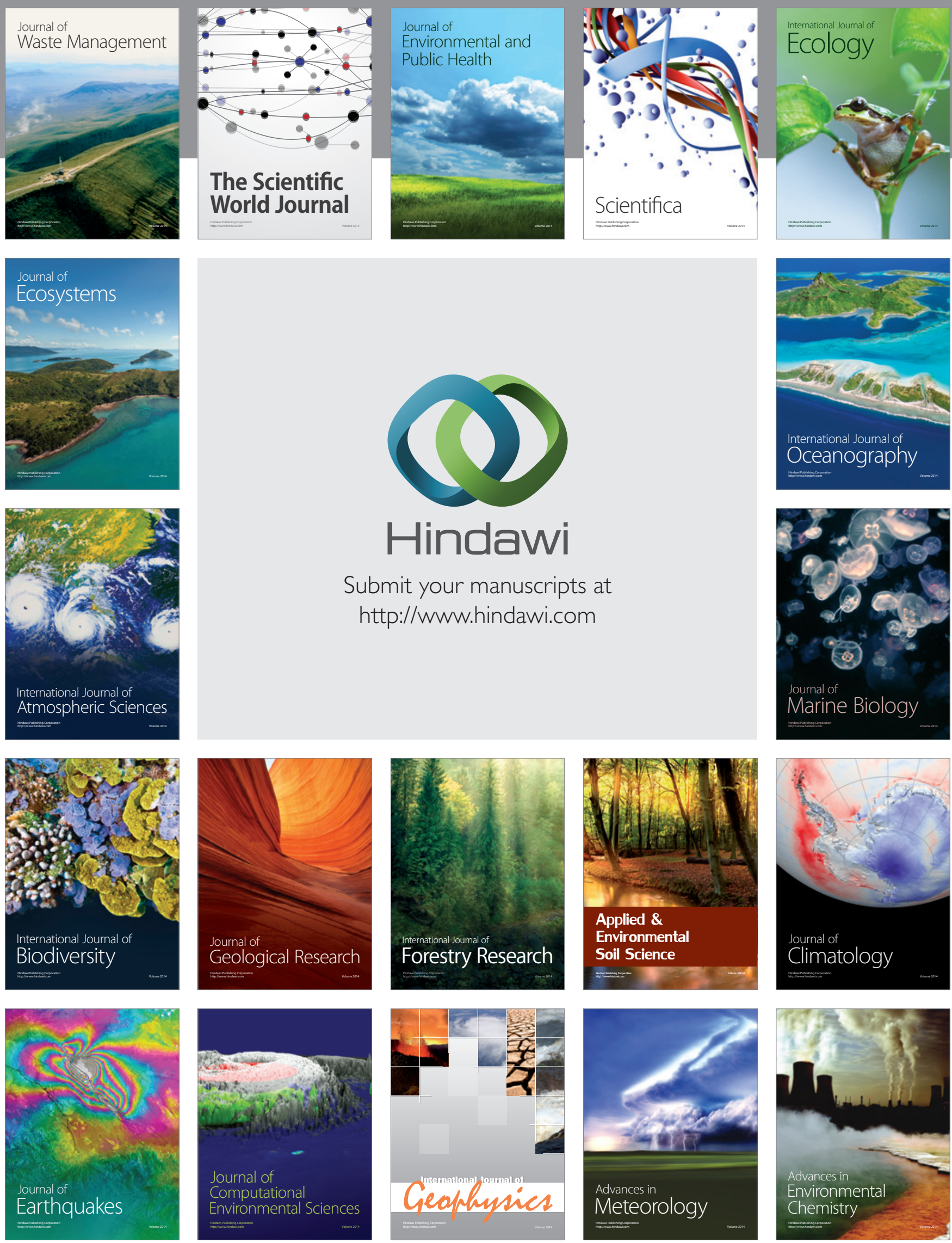